\title{
Housing and management characteristics of calf automated feeding systems in the Upper Midwest of the United States
}

\author{
M. W. Jorgensen, ${ }^{*}$ K. Janni,† A. Adams-Progar, ${ }^{*}$ H. Chester-Jones, ${ }^{*}$ J. A. Salfer, $\ddagger$ and M. I. Endres ${ }^{* 1}$ \\ *Department of Animal Science, and \\ †Department of Bioproducts and Biosystems Engineering University of Minnesota, St. Paul 55108 \\ ¥St. Cloud Regional Office, University of Minnesota Extension, St. Cloud 56301
}

\section{ABSTRACT}

Automated milk feeders are used by dairy producers to manage preweaned calves in group housing, but little is known about how these feeding systems are being used in the United States. To better understand how US dairy producers are operating these systems, this study investigated characteristics of barn design, environment, and management practices on 38 farms in the Upper Midwest of the United States via a questionnaire and on-farm measurements. Farms using automated feeders ranged in size from 7 to 300 calves on site. Natural ventilation was used on $50 \%$ of the farms, followed by barns with mechanical ventilation (39.5\%), tunnel ventilation $(7.9 \%)$, or outdoor facilities (sheltered plastic domes; $2.6 \%)$. Calves were kept in groups of $17.6 \pm$ 9.8 animals (range: 5.9 to 60.5 ) with an average space allowance of $4.6 \pm 2.0 \mathrm{~m}^{2}$ /animal (range: 1.6 to 11.9 ). Calves on these farms received $3.7 \pm 0.75 \mathrm{~L}$ (range: 2 to 6 ) of colostrum, but $22 \%$ of the tested calves had serum total protein values lower than $5.0 \mathrm{~g} / \mathrm{dL}$. Calves had an initial daily allowance of $5.4 \pm 2.1 \mathrm{~L}$ (range: 3 to $15 \mathrm{~L}$ ) of milk or milk replacer, rising to a peak amount of 8.3 $\pm 2.0 \mathrm{~L}$ (range: 5 to $15 \mathrm{~L}$ ) over $18 \pm 11.4 \mathrm{~d}$ (range: 0 to $44 \mathrm{~d}$ ). Milk replacer was fed to calves on $68.4 \%$ of the farms compared with whole milk supplemented with nutrient balancer on $23.7 \%$ and whole milk alone on $7.9 \%$ of the farms. Calves were completely weaned at $56.8 \pm 9.0 \mathrm{~d}$ of age (range: 40 to 85.5 ) and $52.1 \pm 7.5$ d (range: 40 to 79 ) since introduction into the group pen with the feeder. Notably, bacterial contamination of milk was common; the median coliform count was $10,430 \mathrm{cfu} / \mathrm{mL}$ (interquartile range: 233,111; range: 45 to $28,517,000)$ and standard plate count was $2,566,867$ $\mathrm{cfu} / \mathrm{mL}$ (interquartile range: $15,860,194$; range 6,668 to $82,825,000)$ for samples collected from the feeder tube end (or feeder hose). Some areas of deficiency might be

Received February 23, 2017.

Accepted August 21, 2017.

${ }^{1}$ Corresponding author: miendres@umn.edu of concern as they might be influencing the success of using automated calf feeding systems. In particular, a better understanding of the dynamics of pathogen load is needed in both the group pen area and in the automated feeder unit itself, as these reservoirs represent significant risk to calf health and welfare.

Key words: automated calf feeder, calf management

\section{INTRODUCTION}

In the United States dairy calves are commonly kept in individual housing systems (Nordlund, 2008; USDA, 2016). These systems aim to decrease calf-to-calf contact to minimize the transmission of pathogens between animals during the vulnerable preweaning period (Callan and Garry, 2002). Housing calves individually has been linked with reduced levels of both morbidity and mortality (Waltner-Toews et al., 1986a,b). However, these systems have been criticized for restricting calf movement and social interaction (Dellmeier et al., 1985). Individually housed calves may also have a higher labor requirement for feeding and management (Nordlund, 2008). As a result of consumers' animal welfare concerns, legislation and public pressure have largely eliminated individual housing in Europe (Rushen et al., 2008). Many US dairy producers have followed this trend toward group housing preweaned calves in part because of animal welfare concerns and the difficulty of sourcing sufficient farm labor to provide adequate calf care. Concurrent to this trend, computer-controlled automated calf feeding systems are increasing in popularity for the benefits that they offer to producers, including the significant reduction in manual calf-care labor (de Passillé et al., 2004), flexibility in diet administration and weaning, and the increased access to data, which support the management of individual animals in a group-housed system.

The amount of information related to the management of group housing systems in the United States is surprisingly sparse. Because group housing and automated feeding management continue to grow in 
popularity in the United States, and particularly in the Upper Midwest, it is important that the practices being used within these systems be documented. The objectives of this study were to describe housing and management practices employed by producers using automated calf feeding systems in the Upper Midwest of the United States and to investigate the association between milk bacterial counts and automated feeder cleaning practices used on the farms.

\section{MATERIALS AND METHODS}

\section{Data Collection}

At the start of the study, 64 dairy farms were identified as using automated calf feeding systems in the study area (Minnesota, Wisconsin, and northwest Iowa) for some or all of the preweaning period. From this population, 38 farms were randomly selected as a representative sample. Those farms used Förster-Technik (Engen, Germany) automated calf feeders, with the exception of 2 farms: 1 with a Holm \& Laue (Westerrönfeld, Germany), the other with an Urban feeder (Wüsting, Germany). Each farm was visited up to 8 times each, approximately once every 2 mo (repeated cross-sectional measurements) between November 2012 and May 2014. Seasons were defined from the onset of study to December 20, 2012 (fall 1), December 21, 2012, to March 20, 2013 (winter 1), March 21, 2013, to June 20, 2013 (spring 1), June 21, 2013, to September 20, 2013 (summer 1), September 21, 2013, to December 20, 2013 (fall 2), December 21, 2013, to March 20, 2014 (winter 2), and March 21 to May 20, 2014 (spring 2 ). The study was carried out in accordance with the recommendations of the Institutional Animal Care and Use Committee and the protocol was approved by the committee. Consent was granted by the farm operators.

Data were collected through a combination of onfarm measurement, farmer records, and questionnaire. Management practices were gathered via the questionnaire, which was administered by study personnel during farm visits or was left on farm and returned by mail. The questionnaire had 63 questions covering practices from birth through weaning. Feeding management (liquid diet allowance, timing, and weaning pattern) and automated feeder cleaning data were supplemented by information gathered from the automated feeder software.

On farm measurements, including housing and environmental factors, were taken in the pens during each visit. Static housing characteristics were measured during the first farm visit and changes were noted thereafter. These included barn layout and dimensions, ventilation, and pen characteristics. Bedding type, depth, and area were measured at each visit. Bedding wetness was scored at 4 locations within each pen on a 0 to 4 scale $(0=$ dry; $4=$ very wet; Canadian Dairy Research Project, 2011). Environmental measurements, such as barn temperature, humidity, aerial ammonia concentrations, air velocity, and light intensity were taken in 2 calf pens on smaller farms ( 4 or fewer total pens; 33 farms) or in 3 pens ( 5 or more total pens; 5 farms). Thermal environment of the calves was assessed using temperature-humidity loggers (HOBO A23 Pro Series, Onset Corp., Bourne, MA), which were installed in a central location within each calf barn during the first visit. These loggers recorded temperature and humidity hourly throughout the study period. Aerial ammonia concentration was measured using portable $\mathrm{NH}_{3}$ meters (Dräger Pac 7000, Dräger Safety Inc., Pittsburgh, PA) placed at a height of $1.2 \mathrm{~m}$ and set to record a reading once a min during each visit. Air velocity was measured using an anemometer (TSI Velocicheck air velocity meter, model 8330, TSI Inc., Shoreview, MN). Readings were taken across 3 planes, 1 vertical (perpendicular to the ground), and 2 horizontal (one parallel to the ground and one at a $90^{\circ}$ angle from the first) at the feeder station and the resting area. Light intensity was measured at $1 \mathrm{~m}$ height at 2 locations in each calf pen (at the automated feeder station and the resting area at which the most calves were lying down) using a digital portable meter (model TES1337, TES Electrical Electronic Corp., Taiwan, ROC).

Colostrum management quality (success or failure of passive transfer) was evaluated by measuring serum total protein (STP) in a convenience sample of young calves. Blood samples were collected from the jugular vein into vacutainer tubes from all available healthy calves $24 \mathrm{~h}$ to $7 \mathrm{~d}$ of age (up to 12 calves per farm) at each visit. Samples were centrifuged at $1,800 \times g$ for $10 \mathrm{~min}$ and tested for STP using a handheld light refractometer (model HR-200 ATC, AFAB Enterprises, Eustis, FL). The refractometer was calibrated using distilled water before testing the samples collected that day.

Milk samples for bacterial analysis were collected quarterly at each farm from the mixing tank (mixer) and from the feeder tube (or feeder hose) immediately anterior to the nipple from which the calves nurse (tube-end). Once collected, samples were immediately placed on ice and frozen as quickly as possible (within $6 \mathrm{~h}$ ). Milk samples were analyzed for SPC and for coliform bacteria count at the University of Minnesota Veterinary Diagnostic Laboratory (St. Paul, MN). Milk samples were also collected twice (in summer and winter) following a protocol identical to that for the mixing tank sample and analyzed for milk components (fat, protein, and solids) using wet chemistry methods 
Table 1. Medians and interquartile range values summarizing farm factors with nonnormal distributions on dairy farms with automated calf feeders in the Upper Midwest of the United States

\begin{tabular}{lrr}
\hline Factor & Median & Interquartile range \\
\hline Farm size & 367 & 452 \\
$\quad$ No. of lactating cows & 45 & 69.3 \\
$\quad$ No. of calves on feeders & 22.9 & 21.0 \\
Maternity pen & & \\
$\quad$ Bedding depth (cm) & 10,430 & 233,111 \\
Bacterial counts in feeder tube & $2,566,867$ & $15,860,194$ \\
Coliform bacteria count (cfu/mL) & & 28,689 \\
SPC (cfu/mL) & 336 & $2,066,782$ \\
Bacterial counts in mixing tank & 166,916 & \\
Coliform bacteria count (cfu/mL) & & \\
SPC (cfu/mL) & &
\end{tabular}

(AOAC method \#985.09; AOAC method \#930.29; SMEDP \#15.114, respectively). All component analysis was conducted by AgSource Laboratories (Marshfield, WI).

\section{Data Analysis}

The means procedure (PROC MEANS, SAS 9.3, SAS Institute Inc., Cary, NC) was used to calculate means and standard deviations or medians and interquartile range (IQR). Variable skew was visually assessed. For continuous variables that appeared normally distributed, means and standard deviations or ranges are reported. For continuous variables which appeared to be skewed in one direction, median and IQR are reported. The frequency procedure (PROC FREQ, SAS 9.3) was used to report the distribution of categorical variables. Pearson correlation (PROC CORR) was used to evaluate relationships between bacterial counts and automated feeder cleaning practices (significance at $P$ $<0.05)$.

\section{RESULTS AND DISCUSSION}

\section{Data Summary}

Important farm management, housing, and environmental factors are reported in Table 1 (nonnormally distributed factors), Table 2 (normally distributed factors), and Table 3 (questionnaire percent responding).

\section{Farm Demographics}

Farm size varied widely with those milking cows (i.e., not a calf-only facility) reporting a median milking herd size of 367 (IQR: 452; range 60 to 3,000) cows. Median number of calves on automated calf feeders on the farm at any one time was 45 (IQR: 69.3; range 7 to 300). The 3 facilities custom raising calves had a median of 60 calves (range 24 to 62 ). According to USDA (2010) standards, most farms on this study fell into the large (11 study farms; $\geq 500$ cows) and medium (19 study farms; 100 to 499 animals) categories. A lesser proportion of farms would be categorized as small (3 farms; $<100$ cows) and custom calf raisers (3 farms). The majority of the farms (61.1\%) had only Holsteins, with the remainder having Holsteins and crossbred animals $(33.3 \%)$ or Holsteins and Jerseys (5.5\%).

Table 2. Means and SD values summarizing farm factors with normal distribution on dairy farms with automated calf feeders in the Upper Midwest of the United States

\begin{tabular}{|c|c|c|}
\hline Factor & Mean & SD \\
\hline \multicolumn{3}{|l|}{ Maternity pen } \\
\hline Times checked/d & 13.2 & 10.7 \\
\hline \multicolumn{3}{|l|}{ Colostrum management } \\
\hline Colostrum delivered $(\mathrm{L})$ & 3.67 & 0.75 \\
\hline Calf serum total protein $(\mathrm{g} / \mathrm{dL})$ & 5.44 & 0.72 \\
\hline \multicolumn{3}{|l|}{ Group pen bedding } \\
\hline Bedding depth $(\mathrm{cm})$ & 16.3 & 7.1 \\
\hline Straw & 16.8 & 6.9 \\
\hline Cornstalks & 16.3 & 8.1 \\
\hline Wood shavings & 8.0 & 4.0 \\
\hline Soybean straw & 15.1 & 4.4 \\
\hline Sand & 16.1 & 3.9 \\
\hline Bedding changes (times $/ \mathrm{mo}$ ) & 1.2 & 1.0 \\
\hline \multicolumn{3}{|l|}{ Calf grouping } \\
\hline Calf age at grouping (d) & 5.1 & 3.9 \\
\hline Group size (no.) & 17.6 & 9.8 \\
\hline Reported ideal group size (no.) & 19.9 & 9.4 \\
\hline Reported maximum group size (no.) & 26.2 & 11.6 \\
\hline Pen size $\left(\mathrm{m}^{2}\right)$ & 71.0 & 36.0 \\
\hline Stocking density $\left(\mathrm{m}^{2} /\right.$ calf $)$ & 4.6 & 2.0 \\
\hline Age range in pen (wk) & 3.1 & 2.0 \\
\hline \multicolumn{3}{|l|}{ Calf feeding plans } \\
\hline Milk allowance at start (L) & 5.4 & 2.1 \\
\hline Milk allowance at peak (L) & 8.3 & 2.0 \\
\hline Time to reach peak allowance (d) & 18.0 & 11.4 \\
\hline Weaning time $(\mathrm{d})$ & 12.9 & 7.7 \\
\hline Age of calves at weaning start (d) & 44.5 & 6.9 \\
\hline Age of calves at weaning end (d) & 56.8 & 9.0 \\
\hline \multicolumn{3}{|l|}{ Feeder cleaning practices } \\
\hline Automated cleaning frequency (times/d) & 2.5 & 0.8 \\
\hline Circuit cleaning frequency (times/wk) & 3.4 & 3.6 \\
\hline Nipple cleaning frequency (times/wk) & 6.1 & 4.0 \\
\hline Manual tube cleaning frequency (times/wk) & 1.9 & 3.1 \\
\hline Tube replacement (times/yr) & 19.3 & 23.0 \\
\hline
\end{tabular}


Table 3. Frequency of management practices for farms with automated calf feeders in the Upper Midwest of the United States

\begin{tabular}{|c|c|}
\hline Response & $\%$ \\
\hline \multicolumn{2}{|l|}{ Breed } \\
\hline Holstein only & 61.1 \\
\hline Holstein and crossbred & 33.3 \\
\hline Holstein and Jersey & 5.5 \\
\hline \multicolumn{2}{|l|}{ Maternity pen management } \\
\hline Using group pen & 81.8 \\
\hline Using individual pen & 18.2 \\
\hline Pen exposed to elements & 29.4 \\
\hline Pen fully enclosed & 70.6 \\
\hline Pen disinfected at cleaning & 18.2 \\
\hline \multicolumn{2}{|l|}{ Newborn calf care } \\
\hline Licked clean by mother & 76.5 \\
\hline Dried in warming chamber & 14.5 \\
\hline Towel dried & 5.9 \\
\hline Dried with bedding & 2.9 \\
\hline Umbilicus disinfected & 77.8 \\
\hline Iodine & 92.9 \\
\hline Isopropyl alcohol & 3.6 \\
\hline Chlorhexidine & 3.6 \\
\hline Umbilicus not disinfected & 22.2 \\
\hline \multicolumn{2}{|l|}{ Colostrum delivery method } \\
\hline Bottle & 47.1 \\
\hline Esophageal tubing & 41.2 \\
\hline Nurse from dam & 8.8 \\
\hline Nurse and bottle & 2.9 \\
\hline \multicolumn{2}{|l|}{ Colostrum source } \\
\hline Dam only & 67.7 \\
\hline Pasteurized dam only & 11.7 \\
\hline Pooled fresh & 8.8 \\
\hline Other cows & 5.9 \\
\hline \multicolumn{2}{|l|}{ Colostrum evaluated } \\
\hline Colostrometer/refractometer & 35.3 \\
\hline Visual assessment & 52.9 \\
\hline Not assessed & 11.7 \\
\hline \multicolumn{2}{|c|}{ Serum total protein (STP) testing } \\
\hline STP tested always & 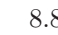 \\
\hline STP tested occasionally & 52.9 \\
\hline STP not tested & 38.2 \\
\hline \multicolumn{2}{|l|}{ Barn construction type } \\
\hline Retrofitted & 60.5 \\
\hline New construction & 39.5 \\
\hline \multicolumn{2}{|l|}{ Ventilation type } \\
\hline Natural ventilation & 50.0 \\
\hline Mechanical ventilation & 39.5 \\
\hline Tunnel ventilation & 7.5 \\
\hline Plastic domes & 2.6 \\
\hline \multicolumn{2}{|l|}{ Positive pressure ventilation } \\
\hline Yes & 86.8 \\
\hline No & 13.2 \\
\hline \multicolumn{2}{|c|}{ Calf pen bedding type ( $\%$ of pens) } \\
\hline Straw & 78.0 \\
\hline Cornstalks & 12.2 \\
\hline Wood shavings & 5.2 \\
\hline Soybean straw & 1.4 \\
\hline No bedding & 2.7 \\
\hline Sand 0 & 0.5 \\
\hline \multicolumn{2}{|c|}{ Bedding wetness score ( $\%$ of tests) } \\
\hline 0 & 87.5 \\
\hline $1-3$ & 12.5 \\
\hline 4 & 2.7 \\
\hline \multicolumn{2}{|l|}{ Pens disinfected at cleaning } \\
\hline Yes & 55.6 \\
\hline No & 44.4 \\
\hline Stocking approach & \\
\hline All-in, all-out & 17.6 \\
\hline Dynamic & 82.4 \\
\hline Liquid diet type & \\
\hline Milk replacer & 68.4 \\
\hline Whole milk with balancer & 23.7 \\
\hline Whole milk & 7.9 \\
\hline
\end{tabular}

\section{Calving Practices}

Close-up cows were group-housed in $81.8 \%$ of the farms. A minority of the farms (11.8\%) housed sick adult animals in the calving pen as well. Producers reported that maternity pens were fully protected from the elements in $70.6 \%$ of facilities, whereas at least 1 side of the maternity pen was exposed in the remaining $29.4 \%$. All but 1 farm reported using bedding in the maternity pen at a median depth of $22.9 \mathrm{~cm}$ (IQR: $21.0 \mathrm{~cm}$, range $=0$ to $61 \mathrm{~cm}$ ), and this bedding was removed and replaced a median 20.8 times/yr (IQR: 40 , range $=2$ to 156). A single farm reported not bedding the maternity pen, while scraping the area twice daily (730 times/yr). Only $18.2 \%$ of the farms reported using a chemical disinfectant at the time of cleaning the maternity pen.

On a national basis, group calving pens are the most common across all farm sizes (USDA, 2016). It was reported that $58.7 \pm 1.8 \%$ of all producers use pens of this type, although this proportion rises for medium $(69.1 \pm 2.7 \%)$ and large $(77.1 \pm 2.0 \%)$ farms to frequencies that are largely comparable to those observed in the current study.

Monitoring of the birthing process varied widely between farms in the current study, with staff visually checking the maternity pen for newly born calves and calving difficulty $13.2 \pm 10.7$ times/d (or once every 1.8 h). Further, observation cameras were used on $14.7 \%$ of the farms, with the remainder not using any special tools to monitor the calving area.

After birth, $61.8 \%$ of the farms in the current study reported using special techniques to stimulate weak calves, although only $40.6 \%$ of the farms had a standard operating procedure for assessing calf vigor. Most farms $(76.5 \%)$ left the calf to be licked clean and dried by the dam, whereas $14.5 \%$ used a warming chamber, $5.9 \%$ used a towel, and $2.9 \%$ used the bedding straw from the maternity pen.

Disinfection of the calf umbilicus was standard procedure on $77.8 \%$ of the farms. A $7 \%$ tincture of iodine was the most popular disinfectant and was used on $92.9 \%$ of the farms that performed umbilical disinfection. Of the remaining farms, 1 used a chlorhexidine product and the other used isopropyl alcohol.

Separating the cow and calf immediately, rather than after a period of days or weeks, has been shown to reduce the intensity of behaviors associated with stress in both the cow and calf (Flower and Weary, 2001) and is thought to minimize the effect of postnatal bonding. In the current study, the maximum length of time a calf was allowed to stay with the mother was $24 \mathrm{~h}$, although this occurred on only $10.5 \%$ of the farms. In the remainder of facilities, calves were removed after an 
average of $1.7 \mathrm{~h}$ (range: 0 to $6 \mathrm{~h}$ ), which was shorter than the length of time to separation observed nationally where $24.2 \%$ of the farms reported separating the animals within $1 \mathrm{~h}$ of parturition rising to $56.2 \%$ removal up to $6 \mathrm{~h}$ (USDA, 2016).

\section{Colostrum Management}

Automated feeder farms in the current study reported delivering $3.67 \pm 0.75 \mathrm{~L}$ (range: 2 to $6 \mathrm{~L}$ ) of colostrum in the first feeding (at an average of $1.7 \mathrm{~h}$ after birth), with the primary delivery method being bottle feeding ( $47.1 \%$ of the farms responding), followed by esophageal tubing $(41.2 \%)$, and a minority $(8.8 \%)$ allowing calves to nurse from the dam or allowing nursing and using a bottle $(2.9 \%)$. Colostrum management on farms using automated feeders appeared to differ from the general dairy population in some key areas. A high percent of the farms in our study (68.6\%) reported feeding the recommended $4 \mathrm{~L}$ of colostrum delivered in the first feeding. This is higher than $21.8 \%$ reported nationally for the United States (representing $42 \%$ of heifer calves; USDA, 2016). The method of delivering the colostrum also differed between study farms and the typical US dairy, with both esophageal tubing of colostrum and allowing the calf to nurse from the dam being used by a higher proportion of operations than has been reported nationally (tubing: $8.1 \%$, nursing: $6.3 \%$; USDA 2016). Method of feeding colostrum was not related to farm size in the current study.

The great majority of the farms $(97.1 \%)$ in the current study only used colostrum from the first milking after birth, although the provenance of this colostrum varied. Fresh colostrum from the calf's own dam was the primary colostrum source on the farms (67.7\%), although pasteurized individual-cow colostrum (11.7\%), pooled fresh colostrum (8.8\%), and fresh colostrum from other cows $(5.9 \%)$ were also used. No primary colostrum source (a mix of sourcing methods) was reported on $5.9 \%$ of the farms. Fresh individual colostrum was also the most popular source nationally (used on $88.6 \%$ of operations), whereas pooled colostrum was less common on automated feeder farms in the current study than observed in a US survey (16.4\% of operations; USDA, 2016).

Tools to measure colostrum quality (i.e., colostrometer, refractometer) were used on only $35.3 \%$ of the farms in the current study, whereas $52.9 \%$ of the farms reported using only a visual assessment and $11.7 \%$ reported not assessing colostrum quality at all. Colostrum replacer was present as a failsafe, or to boost inadequate colostrum, on $44.1 \%$ of the farms.

Only $8.8 \%$ of the farms in the current study reported testing STP on every calf as a method of monitoring the success of immune transfer, although this percentage was higher than reported nationally $(2.1 \%$; USDA, 2010). The STP testing was used as a tool occasionally or in case of an issue on $52.9 \%$ of the farms, and was not used at all on the remaining $38.2 \%$.

Calf STP concentration was $5.44 \pm 0.72 \mathrm{~g} / \mathrm{dL}(\mathrm{n}=$ 925 calves); $22 \%$ were $<5.0$ and $33.6 \%$ were $<5.2 \mathrm{~g} / \mathrm{dL}$. Farm average STP was $5.44 \pm 0.39 \mathrm{~g} / \mathrm{dL}$, but $14.3 \%$ of the farms averaged $<5.0$ and $25.7 \%$ of the farms averaged $<5.2 \mathrm{~g} / \mathrm{dL}$. The rate of failure of passive transfer observed in this study is generally consistent with the national average, in which $19.2 \%$ of calves had IgG levels indicative of inadequate passive transfer (USDA, 2010).

Overall, farms using automated feeding systems appeared to be following some recommended practices when managing colostrum. Although the feeding rates were typically at or above recommended levels, the general lack of colostrum assessment may be undermining the efficacy of management programs. The number of calves exhibiting failure of passive transfer is indicative of the need for further improvement in this area.

\section{Calf Housing and Pen Characteristics}

We found that $60.5 \%$ of the farms in the current study retrofitted existing structures to house their calves and the automated feeding system with the remaining $39.5 \%$ building new facilities. Natural ventilation (barns featuring adjustable curtain walls on at least one side) was used on $50 \%$ of the farms, followed by mechanical ventilation (solid-wall structures featuring one or more exhaust fans) on $39.5 \%$ of the farms. A smaller proportion of the farms had tunnel-ventilated barns (solid-wall structures featuring air inlets at one end and exhaust fans at the other end of the building; $7.9 \%$ ) or outdoor facilities (sheltered plastic domes; $2.6 \%$ ) for their calves. In the latter case, the feeder itself was housed in an indoor, insulated facility.

Proper ventilation is an important factor in controlling the airborne pathogen load, which can contribute to the incidence of respiratory disease in calf facilities. The requirement to distribute fresh outdoor air uniformly without creating drafts is difficult in a calf facility. It is often recommended that calf facilities feature at least some positive pressure ventilation to provide clean, fresh air to calves year-round (Nordlund, 2008). This recommendation was being implemented across automated feeder farms in our study regardless of barn type, with positive pressure tube ventilation in use on $86.8 \%$ of the farms compared with $13.2 \%$ without tubes. It should be noted that while $97 \%$ of the facilities using ventilation tubes were delivering fresh air from outside of the barn, $3 \%$ of the farms were recir- 
Table 4. Seasonal summary of daily average $\left({ }^{\circ} \mathrm{C} ; \pm \mathrm{SD}\right)$, minimum, and maximum temperature recordings on dairy barns with automated calf feeders in the Upper Midwest of the United States

\begin{tabular}{lrrrrrr}
\hline Season & Average & SD & Minimum & SD & Maximum & SD \\
\hline Fall 1 & 1.70 & 1.63 & -1.30 & 2.33 & 4.67 & 1.46 \\
Winter 1 & -0.85 & 4.07 & -4.76 & 5.85 & 3.37 & 3.49 \\
Spring 1 & 11.94 & 2.09 & 7.32 & 4.37 & 16.82 & 3.41 \\
Summer 1 & 21.73 & 0.74 & 16.68 & 2.13 & 26.89 & 1.55 \\
Fall 2 & 6.08 & 2.83 & 1.96 & 4.76 & 10.63 & 3.56 \\
Winter 2 & -3.28 & 4.96 & -7.68 & 6.69 & 1.62 & 4.58 \\
Spring 2 & 11.69 & 2.30 & 9.55 & 4.89 & 13.76 & 1.82 \\
\hline
\end{tabular}

culating air from inside the calf area. A higher proportion of retrofitted calf housing featured solid walls and mechanical ventilation systems $(56.5 \%$ of the farms $)$ than naturally ventilated systems ( $30.4 \%$ of the farms). All of the tunnel ventilated barns were retrofits, and 2 of the 3 also housed older animals in the same facility with preweaned calves. We took a total of 3,282 air velocity readings (6/pen) and found that the maximum recorded air speed was $0.32 \pm 0.39 \mathrm{~m} / \mathrm{s}$ (range: 0 to 2.84 ) at the feeding station and $0.32 \pm 0.39 \mathrm{~m} / \mathrm{s}$ (range: 0 to 3.12 ) at the resting area. Maximum recorded air speed followed a clear seasonal pattern at both areas, peaking during summer at $0.63 \pm 0.66 \mathrm{~m} / \mathrm{s}$ (range 0 to 3.95 ) at the feeder and $0.68 \pm 0.57 \mathrm{~m} / \mathrm{s}$ (range: 0.006 to 4.17 ) at the resting area and being slowest during winter at $0.14 \pm 0.16 \mathrm{~m} / \mathrm{s}$ (range: 0 to 0.81 ) at the feeder and $0.13 \pm 0.16 \mathrm{~m} / \mathrm{s}$ (range: 0 to 1.03 ) at the resting area.

High concentration of aerial ammonia has been linked to irritation of the respiratory tract (Kiorpes et al., 1988 ); recommended maximum is $25 \mathrm{ppm}$. Only $1 \mathrm{op}-$ eration ( $2.6 \%$ of total) exceeded the recommended level at any time of reading. Of 35,466 readings taken, only $120(0.3 \%)$ exceeded $25 \mathrm{ppm}, 222$ readings $(0.6 \%)$ were between 10 and $25 \mathrm{ppm}, 1,755(5.0 \%)$ were between 1 and $10 \mathrm{ppm}$, and 33,374 readings $(94.1 \%)$ detected no ammonia $(<1 \mathrm{ppm})$.

Light intensity was $805 \pm 1,877 \mathrm{~lx}$ (range: 9 to 20,000 ) at the feeder and $1,227 \pm 2,471 \mathrm{~lx}$ (range: 12 to 20,000 ) at the calf resting area. Although lighting approached relatively low levels at times on farms in this study, it was never sufficiently dark to severely inhibit visual acuity.

The majority of facilities kept the automated feeder in a heated space, but did not heat the calf area. A single farm $(2.6 \%)$ kept the calf area heated above a minimum set temperature during colder periods. The thermoneutral zone of the dairy calf ranges between 10 and $26^{\circ} \mathrm{C}$ for newborn calves, expanding to a range of 0 to $23^{\circ} \mathrm{C}$ once the animals reach 1 mo of age (Wathes et al., 1983). Table 4 shows the daily average, minimum, and maximum recorded temperatures on all farms categorized by calendar season. Mean temperature across all farms (the mean of all temperature readings in a $24-\mathrm{h}$ period averaged within a season) was below $0^{\circ} \mathrm{C}$ during both winter $1\left(-0.85 \pm 4.07^{\circ} \mathrm{C}\right)$ and winter $2(-3.28 \pm$ $4.96^{\circ} \mathrm{C}$ ), whereas mean minimum temperature was below $0^{\circ} \mathrm{C}$ during fall $1\left(-1.30 \pm 2.33^{\circ} \mathrm{C}\right)$, winter $1(-4.76$ $\left.\pm 5.85^{\circ} \mathrm{C}\right)$, and winter $2\left(-7.68 \pm 6.69^{\circ} \mathrm{C}\right)$. Maximum temperature was over $23^{\circ} \mathrm{C}$ during summer 1 (26.89 \pm $1.55^{\circ} \mathrm{C}$ ). When comparing temperature by ventilation type (Table 5), only tunnel-ventilated barns never had seasonal mean temperature below $0^{\circ} \mathrm{C}$, whereas no ventilation type had seasonal mean temperature above $23^{\circ} \mathrm{C}$ during this study.

Barn daily mean temperature regularly fell outside of calf thermoneutral zone $\left(0\right.$ to $\left.23^{\circ} \mathrm{C}\right)$. Across farms, the daily mean temperature was below $0^{\circ} \mathrm{C}$ for $127 \pm 56.7 \mathrm{~d}$ and above $23^{\circ} \mathrm{C}$ for $35.4 \pm 10.0$ d. Daily mean temperature was recorded outside the thermoneutral zone on 34 $\pm 10.4 \%$ of days measured during the study. The maximum daily temperature was above the thermoneutral

Table 5. Seasonal daily average temperature $\left({ }^{\circ} \mathrm{C} ; \pm \mathrm{SD}\right)$ recordings on dairy barns with automated calf feeders in the Upper Midwest of the United States by ventilation type

\begin{tabular}{|c|c|c|c|c|c|c|c|c|}
\hline Season & $\begin{array}{l}\text { Naturally ventilated } \\
\quad(\mathrm{n}=19)\end{array}$ & $\mathrm{SD}$ & $\begin{array}{l}\text { Mechanically ventilated } \\
\quad(\mathrm{n}=15)\end{array}$ & $\mathrm{SD}$ & $\begin{array}{l}\text { Tunnel ventilated } \\
\qquad(\mathrm{n}=3)\end{array}$ & $\mathrm{SD}$ & $\begin{array}{l}\text { Igloo } \\
(\mathrm{n}=1)\end{array}$ & SD \\
\hline Fall 1 & 0.90 & 1.35 & 2.42 & 1.58 & - & - & - & - \\
\hline Winter 1 & -2.90 & 1.80 & 0.71 & 0.71 & 4.76 & 0.09 & -4.21 & - \\
\hline Summer 1 & 21.72 & 0.80 & 21.78 & 0.59 & 22.22 & 0.87 & 20.12 & - \\
\hline Fall 2 & 4.66 & 1.14 & 7.22 & 3.02 & 10.75 & 5.00 & 3.90 & - \\
\hline Winter 2 & -5.57 & 2.64 & -0.72 & 5.61 & 4.47 & - & -8.37 & - \\
\hline
\end{tabular}


zone $\left(>23^{\circ} \mathrm{C}\right)$ on $36.7 \pm 6.7 \%$ of days, and the minimum daily temperature was outside this zone $\left(<0^{\circ} \mathrm{C}\right)$ on 38.5 $\pm 13.6 \%$ of days. The daily mean temperature was outside the thermoneutral zone in mechanically ventilated barns on $30.2 \pm 10.4 \%$ of days, compared with 39.7 $\pm 5.1 \%$ in naturally ventilated barns, $15.1 \pm 7.1 \%$ in tunnel-ventilated barns, and $39.0 \%$ in outdoor plastic domes (single farm). Farms using tube ventilation had a daily mean temperature outside the thermoneutral zone on $34.5 \pm 10.0 \%$ of days, compared with $31.9 \pm$ $14.6 \%$ in farms without ventilation tubes.

\section{Bedding and Pen Cleaning}

Calf pens typically featured a bedding substrate. Straw was the most common bedding material, used in 435 of the 558 pens ( $78.0 \%$ of pens) in which bedding characteristics were measured. Other bedding materials included cornstalks (12.2\%), wood shavings (5.2\%), soybean straw $(1.4 \%)$, and sand $(0.5 \%)$. One automated feeding system was installed in a retrofitted swine barn, which housed calves on a slatted metal floor and in which bedding was not used. Bedding depth measured at the time of visit was $16.3 \pm 7.1 \mathrm{~cm}$ (range: 2.5 to $40.6 \mathrm{~cm}$ ). When categorized by bedding type, straw was bedded at the greatest depth $(16.8 \pm 6.9 \mathrm{~cm})$, followed by cornstalks $(16.3 \pm 8.1 \mathrm{~cm})$, sand $(16.1 \pm 3.9 \mathrm{~cm})$, soybean straw $(15.1 \pm 4.4 \mathrm{~cm})$, and wood shavings $(8.0$ $\pm 4.0 \mathrm{~cm}$ ). It should be noted that sand was used as the primary bedding substrate only during summer and was replaced with straw or cornstalks in colder months. Although temperatures can regularly fall outside of the calf's thermoneutral zone, bedding can provide a mechanism to support thermoregulation (Nordlund, 2008).

Bedding wetness can affect its effectiveness as a tool for thermoregulation, but excessively wet bedding did not appear to be a major issue on automated feeder farms in the current study. Bedding wetness was tested in 547 pens $(2,188$ individual tests at 4/pen). Most bedding wetness tests scored 0, or completely dry (1915 tests, 87.5\%), with 273 tests detecting at least some level of wetness (score of 1 or greater; 12.5\%). Only 59 samples $(2.7 \%)$ received the highest score for wetness, representing a small proportion of the total samples taken, but 1 or more samples with a wetness score of 4 were detected in 50 pens (9.1\%). The farm average sum of bedding wetness scores was $1.1 \pm 0.9$ (range: 0 to 4.2) of a possible maximum of 16 per pen (4 measurements with a maximum value of 4 each).

Producers reported changing the bedding in automated feeder pens $1.2 \pm 1.0$ times/mo. In addition to affecting the thermal environment of the calf, the regu- lar addition of clean, dry bedding has been reported as an effective method for separating calves from enteric pathogens on the pen floor (McGuirk, 2008). The cleaning and disinfecting of pens between calf groups is also recommended as a management practice to maintain biosecurity and disrupt disease cycles (Castro-Hermida et al., 2006). Despite the availability and efficacy of multiple sanitizing agents (Patterson et al., 2005; Quilez et al., 2005), only $55.6 \%$ of the farms reported the regular washing and disinfecting of the pens between groups.

\section{Insects}

Insect pests were reported as an issue in the group housing area on $58.3 \%$ of the farms, compared with $41.7 \%$ not reporting major pest issues. Insecticide spray was used to control fly populations on $67.6 \%$ of the farms, whereas $27.3 \%$ of producers used a feed product with larvicide as an ingredient. Nonchemical pest control measures were reported on $41.9 \%$ of the farms. Flies may compromise sanitation efforts and can act as a vector for pathogenic organisms such as Cryptosporidium parvum (Graczyk et al., 1999).

\section{Calf Grouping}

Most study farms reported that calves were kept individually for a short period following birth in order for calves to develop the physical capacity to cope with group housing. Only $25.7 \%$ of the farms in the current study reported grouping calves at $\mathrm{d} 1$ of age. Calf age at grouping was $5.1 \pm 3.9 \mathrm{~d}$ (range: 0 to $14 \mathrm{~d}$ ). Disease incidence in calves peaks during the second week of life, so it has been recommended that grouping be delayed until after this period (Svensson et al., 2003). If calves have adequate passive immune transfer and are strong enough to gain regular access to critical resources in a group setting, waiting for $14 \mathrm{~d}$ may not be necessary. More research is needed on the effect of age at introduction to group housing on calf health and welfare.

The group size measured on farms in the present study was $17.6 \pm 9.8$ animals (range: 5.9 to 60.5 ). On the management questionnaire, producers reported an ideal group size of $19.9 \pm 9.4$ calves/pen and a maximum tolerable group size of $26.2 \pm 11.6$ animals. Previous studies found that group size had a significant effect on calf health and performance (Svensson et al., 2003), although the exact relationship is not necessarily clear. We found that most automated feeding system operators in our study did not exceed upper limits for group size suggested by manufacturers (25 to 30 calves).

Calf pen size within these facilities ranged from 15.5 to $237 \mathrm{~m}^{2}$, although these sizes represent the extremes. 
The farm with the largest pen size also had the largest average group size (60.5 calves), which was not typical. The mean per-farm pen size for group-housed calves was $71 \pm 36 \mathrm{~m}^{2}$. Pen size was commonly related to the number of calves being housed, although this was not always the case. Average pen space allowed per calf was $4.6 \pm 2.0 \mathrm{~m}^{2}$ (range: 1.6 to $11.9 \mathrm{~m}^{2}$ ). Because overstocking is detrimental to calf health, it is recommended that calves be allowed a minimum amount of resting space of 2.3 to $2.8 \mathrm{~m}^{2}$ (FASS, 2010) and this minimum limit was met in $93.1 \%$ of pens in the current study.

The age difference between the oldest and youngest animals in a pen was $3.1 \pm 2.0 \mathrm{wk}$ (range: 0.3 to $10 \mathrm{wk}$ ). Weaned and preweaned animals were kept together in the same pen on $61.1 \%$ of the farms, whereas $38.9 \%$ of producers removed animals on the day of weaning. Although the measurements taken represent a static example of calf group size, in reality group sizes tended to be significantly more dynamic with calves being added and removed from the group upon reaching certain age limits. Only $17.6 \%$ of the farms used an all-in/all-out stocking system in which calf groups were relatively static once the pen had been filled. Much more common (82.4\% of the farms) was a dynamic grouping system in which calves were added and removed from the automated feeder as individuals or in small groups. These continuous flow systems effectively increased the group size that a calf was exposed to during the preweaning period likely increasing the risk of infection from other pen mates. However, because of farm size and economic considerations most farms did not implement all-in/ all-out systems.

\section{Feeding Plans}

The capability of automated feeding systems to deliver more milk, and more feedings per day, to calves was reflected in the relatively high milk allowances observed on the majority of the farms in the current study. When introduced to the automated feeder, calves were started at a daily allowance of $5.4 \pm 2.1 \mathrm{~L}$ (range: 3 to $15 \mathrm{~L}$ ) of milk or milk replacer. This increased to a peak amount of $8.3 \pm 2.0 \mathrm{~L}$ (range: 5 to $15 \mathrm{~L}$ ). It took $18 \pm 11.4 \mathrm{~d}$ (range: 0 to $44 \mathrm{~d}$ ) for calves to reach the peak milk allowance. Milk replacer was fed on $68.4 \%$ of the farms compared with whole milk supplemented with nutrient balancer on $23.7 \%$ and whole milk alone on $7.9 \%$ of the farms.

Although the amount of milk being fed in automated feeding systems was higher than in most conventional systems, there is potential that the liquid diet being delivered to calves is not mixed precisely to specifications. Automated feeders, particularly those feeding a powdered milk replacer, require regular maintenance to prevent the powder from bridging, caking, or otherwise clogging the dispensing system. The overall fat content of the liquid diet $(\mathrm{n}=73)$ was $2.8 \pm 0.7 \%$ (range: 1.2 to 4.0 ), protein content was $3.3 \pm 0.7 \%$ (range: 1.9 to 5.1 ), and TS were $12.2 \pm 1.9 \%$ (range: 11.1 to 18.0 ). For those farms using milk replacer, fat content was $2.4 \pm 0.5 \%$ (range: 1.2 to 3.7 ), protein was $3.1 \pm 0.7 \%$ (range: 1.9 to 5.1 ), and TS were $12.0 \pm 2.2 \%$ (range: 7.0 to 18.0). Farms feeding supplemented whole milk had fat content of $3.4 \pm 0.6 \%$ (range: 1.7 to 4.0 ), protein of $3.8 \pm 0.4 \%$ (range: 3.2 to 4.6 ), and TS of $12.8 \pm 1.1 \%$ (range: 10.3 to 14.3). Farms using whole milk alone had fat content of $3.5 \pm 0.3 \%$ (range: 3.0 to 3.9 ), protein of $3.4 \pm 0.3 \%$ (range: 3.0 to 3.9 ), and TS of $12.0 \pm 0.5 \%$ (range: 11.0 to 12.6). The apparent difference between farms using milk replacer and those using whole-milkbased diets indicates a need to further investigate calibration and dispensing issues in automated feeders and to encourage regular maintenance to ensure proper feeder function.

In total, $76.3 \%$ of the farms fed a medicated liquid diet (milk or milk replacer that included antibiotics or coccidiostats in the product delivered to calves) with just $23.7 \%$ feeding a nonmedicated diet. Feeding of a medicated liquid diet was more prevalent on farms feeding milk replacer, being used by $89.7 \%$ of these farms, when compared with $33.3 \%$ of the farms feeding a supplemented or nonsupplemented whole milk.

A generally gradual weaning period lasted $12.9 \pm 7.7$ d (range: 3 to $42 \mathrm{~d}$ ) from first reduction to complete removal from a liquid diet. While traditional systems make managing a gradual weaning program difficult, the process is relatively simple to administer in automated feeders. The average age at weaning in the United States was reported to be 58.8 d (USDA, 2010). The automated feeding operations on this study were very similar to this national average, and began weaning calves from the liquid diet at $44.5 \pm 6.9 \mathrm{~d}$ of age (range: 32 to 60 ) and time on the feeder of $39.3 \pm 6.3$ d (range: 20 to 59). Calves were completely weaned at $56.8 \pm 9.0 \mathrm{~d}$ of age (range: 40 to 85.5 ) and $52.1 \pm 7.5 \mathrm{~d}$ (range: 40 to 79 ) since introduction into the group pen with the feeder.

\section{Calf Monitoring}

Most individuals supervising the calf area also had other farm labor responsibilities, but $28.9 \%$ of the farms reported having an employee (or family member) whose primary responsibility was to care for the calves. Automated feeders are designed to provide calf managers information on individual animals' amount of milk con- 
sumed per day and per meal, drinking speed, number of visits to the feeder unit for which the calf received milk (rewarded visits) and did not receive milk (unrewarded visits), and the number of times a calf stops drinking in the middle of a meal (break-offs). Although more work needs to be done to determine the strength of relationship between these behavioral factors and actual health outcomes, most producers relied on one or more of them to identify potentially sick animals.

Of the data reported by the automated feeding system, producers reported using the percent of allotment consumed (milk intake) to monitor calf health most frequently ( $77.4 \%$ of the producers) to identify potentially sick calves, followed by measurement of drinking speed $(55.9 \%)$. The next most popular measure was the frequency of break-offs (when the calf stops drinking before a meal has been fully consumed), used by $29.4 \%$ of the producers. Neither the number of times the calf visited the machine (used by $5.9 \%$ of the producers) nor the number of unrewarded visits to the machine (used by $2.9 \%$ of the producers) were widely used. Almost half of the producers (44.7\%) did not use a specific behavioral measure to monitor calf health, relying instead on the automated feeder's default algorithms to detect sick animals. Of those farms that focused on one or more specific measures of calf health $(55.3 \%$ of the farms), $52.4 \%$ focused on a single factor, $42.9 \%$ used 2 factors, and $4.8 \%$ used 3 factors.

\section{Painful Procedures}

Thirty-five farms reported dehorning and 18 farms reported castrating males on site. Of those, thermal (hot iron) dehorning was the most common practice ( $57.1 \%$ of the farms), followed by use of a caustic paste (28.6\% of the farms) and physical removal of the horn bud ( $14.3 \%$ of the farms). These percentages are similar to US practices for raising dairy heifers, in which hot iron dehorning is the most popular, followed by caustic paste, and then physical removal (USDA, 2010).

Anesthesia was rarely reported as being used at the time of dehorning, being used by $14.7 \%$ of the farms (20\% of the farms using chemical paste, $15 \%$ of the farms using thermal dehorning), and analgesic pain relief was used on only $5.9 \%$ of the farms (10\% of the farms using chemical paste, $5 \%$ of the farms using thermal dehorning). Of the farms that kept bull calves for a portion or all of the preweaning period, rubber band castration was used on $72.2 \%$ of the farms, whereas surgical castration was used on $27.8 \%$. No farms used anesthesia at the time of castration, and only $5.6 \%$ (1 farm using surgical castration) of the farms provided analgesic pain relief after the procedure.

\section{Feeder Cleaning, Management, and Bacterial Contamination}

The median coliform count on milk samples was $10,430 \mathrm{cfu} / \mathrm{mL}$ (IQR 233,111; range 45 to $28,517,000$ ) in the feeder tube end and $336 \mathrm{cfu} / \mathrm{mL}$ (IQR 28,689; range 0 to $25,621,330)$ in the mixing jar. The median SPC was $2,566,867 \mathrm{cfu} / \mathrm{mL}$ (IQR 15,860,194; range 6,668 to $82,825,000$ ) in the feeder tube end and 166,916 (IQR $2,066,782$; range 125 to $59,396,100$ ) in the mixing jar. When comparing the best- and worst-performing farms (Table 6), the differences in bacterial count between median and IQR of the top 10th and bottom 10th percentile performing farms was very large. Although bacterial counts in the worst-performing farms represent a very real risk to calf health, the performance of the best farms indicates that it is possible to mix and deliver a liquid diet that meets recommended bacterial counts. It has been recommended that bacterial contamination of milk fed to calves be below $100,000 \mathrm{cfu} / \mathrm{mL}$ for SPC and 10,000 cfu/mL for coliform bacteria (McGuirk and Collins, 2004).

Automated feeders are designed with certain cleaning tools and procedures integrated into the system, but research determining the effectiveness of these procedures is very limited. In addition to this, some cleaning procedures require the operator to manually initiate the process on the feeder controller, a fact that was often not known by operators at the time of installation. It is possible that farm operators were not aware about the liquid diet contamination. Only $28.1 \%$ of the farms reported ever using a bacterial analysis to monitor feeder sanitation, $37.5 \%$ did not monitor sanitation, and $31.3 \%$ reported using only a visual assessment to monitor sanitation. Visual observation is unlikely to give a good measure of bacterial contamination.

Cleaning of the automated feeders varied widely among farms, particularly for those tasks that must be initiated or fully performed by human staff. Automated feeders were set up to execute an automated cleaning function (of the feed mixing jar) $2.5 \pm 0.8$ times/d (range: 1 to 4). Producers reported performing the circuit cleaning function (an automated cleaning of machine tubing that must be manually initiated) $3.4 \pm$ 3.6 times/wk (range: 0 to 4 ) with $11.4 \%$ of the farms never running this function. Farmers reported changing and sanitizing the nipples from which the calves nurse $6.1 \pm 4.0$ times/wk (range: 0.2 to 14 ). The tubes (or hoses) leading from the mixing unit to the nipple were manually cleaned $1.9 \pm 3.1$ times/wk (range: 0 to 14 ), with $36.4 \%$ of the farms never cleaning them. These tubes were replaced $19.3 \pm 23.0$ times/yr (range: 1 to 104). 
Unsurprisingly, we detected associations among milk bacterial counts, with contamination in one location (the feeder tube end or mixing jar) increasing the likelihood of measuring contamination in another. We also detected associations between SPC and coliform counts. The coliform count of the feeder tube end samples was related to that from the mixing jar $(\mathrm{r}=0.30, P<$ 0.001 ) and the same relationship was detected for SPC $(\mathrm{r}=0.48, P<0.001)$. Bacterial counts in the feeder tube end were typically higher than those in the mixing jar, which is reflective of the fact that the cleaning functions of the mixing jar were totally automated whereas those for the tube were not automated at the time of the study. Despite this, it appears that both sites can serve as a reservoir for potentially pathogenic organisms.

We also found associations between milk bacterial counts and the frequency of performing cleaning procedures reported by producers. The coliform count from the mixing jar was negatively associated with the frequency of automated mixer cleaning $(\mathrm{r}=-0.26, P<$ $0.001)$ as was the SPC of the mixing jar $(\mathrm{r}=-0.32, P$ $<0.001$ ). The SPC from the feeder tube end was correlated with the frequency of automated mixer cleaning ( $\mathrm{r}=-0.15, P=0.048)$ and the frequency of circuit cleaning $(\mathrm{r}=-0.28, P<0.001)$. The coliform count from the tube was not associated with any of the cleaning factors. It is encouraging to see that more frequent cleaning of the automated feeder unit, including both automated and manual procedures, was associated with a reduced level of bacterial contamination. The relationship between automated feeder cleaning frequency and milk bacterial counts is not well understood, and while more frequent automated and manual cleaning of the machines has been shown to be associated with reduced bacterial contamination in milk, certain cleaning functions may actually loosen built-up biofilms in the machine and increase bacterial content in the short term (Dietrich et al., 2015). More research should be conducted to determine what factors affect bacterial contamination of the milk fed to calves in automated systems, including on-farm cleaning procedures and the environment in which the feeder is housed.

\section{CONCLUSIONS}

This study provided novel information about various management practices and housing characteristics for farms using automated feeders for preweaned calves in the Upper Midwest of the United States. Some areas of deficiency might be of concern as they might be influencing the success of using these systems. In particular, a better understanding of the dynamics of pathogen load is needed in both the group pen area and in the 
automated feeder unit itself, as these reservoirs represent significant risk to calf health and welfare.

\section{ACKNOWLEDGMENTS}

We thank all the dairy producers who participated in the study. In addition, we thank Luis Espejo (St. Augustine, FL) for help with statistical analysis. We thank the following students at the University of Minnesota for help with data entry: Nathan Bos, Kelly Froehlich, Andrew Hetke, Andrew Plumski, and Michael Schmitt. This project was supported by Agriculture and Food Research Initiative competitive grant no. 2012-6702119280 from the USDA National Institute of Food and Agriculture (Washington, DC).

\section{REFERENCES}

Callan, R. J., and F. B. Garry. 2002. Biosecurity and bovine respiratory disease. Vet. Clin. North Am. Food Anim. Pract. 18:57-77. https://doi.org/10.1016/S0749-0720(02)00004-X.

Canadian Dairy Research Project. 2011. Stall Wetness Cluster Project. Accessed Oct. 1, 2012. https://www.dairyresearch.ca/pdf/2D -stall\%20bedding\%20wetness\%20sop_221210.pdf.

Castro-Hermida, J. A., C. Carro-Corral, M. Gonzalez-Warleta, and M. Mezo. 2006. Prevalence and intensity of infection of Cryptosporidium spp. and Giardia duodenalis in dairy cattle in Galicia (NW Spain). J. Vet. Med. B Infect. Dis. Vet. Public Health 53:244-246. https://doi.org/10.1111/j.1439-0450.2006.00946.x.

de Passillé, A. M., J. Rushen, and D. Weary. 2004. Designing good environments and management for calves. Adv. Dairy Technol. $16: 75-89$

Dellmeier, G. R., T. H. Friend, and E. E. Gbur. 1985. Comparison of four methods of calf confinement II: behavior. J. Anim. Sci. 60:1102-1109. https://doi.org/10.2527/jas1985.6051102x.

Dietrich, A. M., W. A. Knauer, S. A. Godden, C. S. Petersson-Wolfe, and R. E. James. 2015. Factors associated with aerobic plate count, coliform count, and log reduction of bacteria in automated calf feeders. J. Dairy Sci. 98(E-Suppl.2):214. (Abstr.)

FASS. 2010. Guide for the care and use of agricultural animals in research and teaching. 3rd ed. FASS, Champaign, IL.

Flower, F. C., and D. M. Weary. 2001. Effects of early separation on the dairy cow and calf: 2. Separation at 1 day and 2 weeks after birth. Appl. Anim. Behav. Sci. 70:275-284. https://doi.org/10 .1016/S0168-1591(00)00164-7.

Graczyk, T. K., M. R. Cranfield, R. Fayer, and H. Bixler. 1999. House flies (Musca domestica) as transport hosts of Cryptosporidium parvum. Am. J. Trop. Med. Hyg. 61:500-504.
Kiorpes, A., D. Butler, R. Dubielzieg, and K. Beck. 1988. Enzootic pneumonia in calves: Clinical and morphologic features. Compend. Contin. Educ. Pract. Vet. 10:248-258.

McGuirk, S. M. 2008. Disease management of dairy calves and heifers. Vet. Clin. North Am. Food Anim. Pract. 24:139-153. https://doi .org/10.1016/j.cvfa.2007.10.003.

McGuirk, S. M., and M. Collins. 2004. Managing the production, storage and delivery of colostrum. Vet. Clin. North Am. Food Anim. Pract. 20:593-603. https://doi.org/10.1016/j.cvfa.2004.06.005.

Nordlund, K. V. 2008. Practical considerations for ventilating calf barns in winter. Vet. Clin. Food. Anim. 24:41-54. https://doi.org/ 10.1016/j.cvfa.2007.10.006.

Patterson, G., P. S. Morley, K. D. Blehm, D. E. Lee, and M. Dunowska. 2005. Efficacy of directed misting application of a peroxygen disinfectant for environmental decontamination of a veterinary hospital. J. Am. Vet. Med. Assoc. 227:597-602. https://doi.org/10 $.2460 /$ javma.2005.227.597.

Quilez, J., C. Sanchez-Acedo, C. Avendano, E. del Cacho, and F. Lopez-Bernard. 2005. Efficacy of two peroxygen based disinfectants for inactivation of Cryptosporidium parvum oocysts. Appl. Environ. Microbiol. 71:2479-2483. https://doi.org/10.1128/AEM 71.5.2479-2483.2005.

Rushen, J., A. M. de Passillé, M. A. G. von Keyserlingk, and D. M. Weary. 2008. Housing for growing animals. Pages $181-210$ in The Welfare of Cattle. C. Phillips, ed. Springer, Dordrecht, the Netherlands.

Svensson, C., K. Lundborg, U. Emanuelson, and S. O. Olsson. 2003. Morbidity in Swedish dairy calves from birth to 90 days of age and individual calf-level risk factors for infectious diseases. Prev. Vet. Med. 58:179-197. https://doi.org/10.1016/S0167-5877(03)00046 -1 .

USDA. 2010. Dairy 2007, heifer calf health and management practices on U.S. dairy operations. USDA-APHIS-VS, CEAH. Fort Collins, CO. Accessed Jul. 1, 2016. https://www.aphis.usda.gov/animal _health/nahms/dairy/downloads/dairy07/Dairy07_ir_CalfHealth .pdf.

USDA. 2016. Dairy 2014. Dairy cattle management practices in the United States, 2014. USDA-APHIS-VS- CEAH-NAHMS. Fort Collins, CO. Accessed Jul. 1, 2016. https://www.aphis.usda.gov/ animal_health/nahms/dairy/downloads/dairy14/Dairy14_dr PartI.pdf.

Waltner-Toews, D., S. Martin, and A. Meek. 1986a. Dairy calf management, morbidity and mortality in Ontario Holstein herds. III. Association of management with morbidity. Prev. Vet. Med. 4:137-158. https://doi.org/10.1016/0167-5877(86)90019-X.

Waltner-Toews, D., S. Martin, and A. Meek. 1986b. Dairy calf management, morbidity and mortality in Ontario Holstein herds. IV. Association of management with mortality. Prev. Vet. Med. 4:159 171. https://doi.org/10.1016/0167-5877(86)90020-6.

Wathes, C. M., C. Jones, and A. Webster. 1983. Ventilation, air hygiene and animal health. Vet. Rec. 113:554-559. https://doi.org/ $10.1136 / v r .113 .24 .554$. 